GLOBAL MEDICAL ETHICS

\title{
Human embryonic stem cell research debates: a Confucian argument
}

\author{
D F-C Tsai
}

J Med Ethics 2005;31:635-640. doi: 10.1136/jme.2005.011924

Correspondence to:

D F-C Tsai, Department of Social Medicine and Department of Family Medicine, National

Taiwan University College of Medicine, Department of Medical Research, National Taiwan University Hospital, No 1, Section 1, Jen-Ai Road, Taipei, 100, Taiwan; fctsai@ha.mc.ntu. edu.tw

Received 12 February 2005 Accepted for publication 16 February 2005
Human embryonic stem cell research can bring about major biomedical breakthroughs and thus contribute enormously to human welfare, yet it raises serious moral problems because it involves using human embryos for experiment. The "moral status of the human embryo" remains the core of such debates. Three different positions regarding the moral status of the human embryo can be categorised: the "all" position, the "none" position, and the "gradualist" position.

The author proposes that the "gradualist" position is more plausible than the other two positions. Confucius's moral principle of jen, which proposes a unique theory of "love of gradation", and the principle of yi, which advocates "due treatment for persons", are then explored. The author then argues that our moral obligations to do good to other living organisms, persons, and our families are different. Putting together the "gradualist" position on the human embryo, and Confucius's theories of "love of gradation" and "due treatment for persons", the author concludes that the early embryo has less ethical significance than the later fetus and adult human. The moral obligation we have toward persons is clearer and stronger than that which we have toward human embryos. Embryo research is justifiable if it brings enormous welfare to human persons that cannot be otherwise achieved. The "love of gradation" requires us, however, to extend love and respect towards other entities according to their different status. We should therefore be very cautious in using human embryos for research, acknowledging the gradualist nature of their moral status.
$\mathrm{T}$ he ethical issues arising from the use of human embryonic stem cells in biomedical research have attracted the spotlight on the bioethics stage at the end of the 20th century and the beginning of the 21st. Questions to do with such use of stem cells also shape crucial public policies, which will have a major effect on both scientific advancement and future human welfare. Stem cells, which may be retrieved from the early embryo; the primordial crest of the aborted fetus; blood from the umbilical cord; certain adult tissue such as bone marrow or cadaver brain cells, and even by "parthenogenesis", could be cultivated and developed into more than 300 kinds of human cells and tissues. These could then be used to replace damaged, degenerated, or infected body components. Stem cell therapy may mean that some day many incurable diseases such as diabetes, strokes, dementia, spinal injury, heart disease, Parkinsonism, cancer, and birth defects will be curable. Moreover, if the "somatic cell nuclear transfer" (SCNT) technique is employed to create cloned embryos for the purpose of deriving specifically designed, genetically identical stem cells, then this "therapeutic cloning" method could introduce an era of "rejection free transplantation medicine" and "regeneration medicine". Miraculous cures- "the blind can see; the deaf can hear, and the crippled can walk" - will no longer be the privilege of Jesus Christ.

Although human stem cell research could make possible such major biomedical breakthroughs and contribute enormously to human welfare, it raises serious moral problems because it involves using human embryos in experiments. The ethical issues at stakes are: when does human life begin to matter morally? Can we draw a morally significant line between a gamete and an infant? What is the moral status of human embryos? Can we sacrifice a human embryo to promote human welfare?

\section{THE MORAL STATUS OF THE HUMAN EMBRYO: A "GRADUALIST" POSITION}

According to Warren, to have moral status is to have moral standing. It is to be an entity toward which moral agents have, or can have, moral obligation. If an entity has moral status, then we may not treat it in just any way we please; we are morally obliged to give weight in our deliberations to its needs, interests, or wellbeing. ${ }^{1}$ Different times or events have been proposed to define when human embryo starts to possess such a moral status. These include: from conception; 14 days, 40 days, and 90 days from conception; quickening; consciousness; viability, and at birth. The plausibility of these times or events will not be explored here. Nevertheless, three categories of the moral status of human embryos can be generally classified: The "all position", the "none position", and the "gradualist position" or "special entity position".

\section{The "all position"}

This position holds that human life begins from conception and that using human embryos for research is unethical because embryos possess full human status from the moment of their conception or creation. Traditional thinking presupposes that the inherent value of all human beings-the species Homo sapiens-is an indisputable, self evident truth. Devine described this as the "species principle": human organisms, no matter their degree of maturity or decay, are inherently valuable, in a sense that the non-human animal, robot, or extraterrestrial life is not. ${ }^{2}$ The JudaeoChristian traditions sees human beings as having been created in the image of God, and human dignity and rights flowing from God's creation. Therefore they also assert the sacred and inviolable value of all human beings. 


\section{The "none position"}

This position argues that on the contrary human embryos are merely cells or property that have no moral status and therefore deserve no special moral concern. They lack the characteristics of "personhood"; therefore they are not persons and deserve no rights or respect. That is, were a "human being" not at the same time a "person", he would have no human rights, because "Persons, not humans, are special". ${ }^{3}$ How is personhood defined in modern bioethics? Fletcher proposed a list of "indicators of humanhood" including "self awareness, self control, a sense of the future, a sense of the past, the capacity to relate to others, concern for others, communication and curiosity". ${ }^{4}$ Singer distinguished two meanings of human being-first, a human being is a member of the species Homo sapiens, and second, a human being is a being who possesses the qualities of personhood as defined by Fletcher. Only human beings in the second sense are "persons" who deserve rights and respect." Tooley said that a person must have the "awareness of self as a continuing entity" and be "capable of having an interest in his own continued existence". ${ }^{6}$ Whereas for Harris a person is "any being capable of valuing its own existence". ${ }^{7}$ Engelhardt proposed that those who have the following four characteristics: self consciousness, rationality, freedom to choose, and who are in possession of a sense of moral concern, are "persons in the strict sense". In his view, human beings who lack those characteristics are merely "persons of social sense" (Engelhardt," pp 136-7). Accordingly, human embryos, who are lacking in these characteristics of personhood, cannot be counted as persons and have no moral status.

\section{The "gradualist position"}

This position generally regards human embryos as potential human beings, but not yet humans, possessing a "special status", which is higher than "none" but less than "all", who are thus deserving of certain degrees of respect, which should increase along with their development. Because human embryos hold neither "all" nor "none" moral status, the respect they are due has no absolute priority and might properly be weighed against the benefits arising from research on them, particularly in the early stages of their development.

\section{SOME COMMON SOCIAL MEDICAL LEGAL PRACTICES}

All three positions have their loyal proponents with certain distinctive cultural/religious/historical backgrounds. Some longstanding medical and social practices seem mostly, however, to support the gradualist position, which therefore would seem to deserve careful consideration. Six points need to be made here.

1. Although more than two thirds of fertilised ova are lost naturally before implantation, we do not take aggressive measures to save them even though medical advancement has provided us with such knowledge and the means of rescue-for example, the early detection of pregnancy plus hormonal therapy in some cases, as performed in infertility treatment.

2. In the case of early abortion or miscarriage, neither as parents nor as a society do we usually respond as though an infant, a child, or a fellow person has been lost. We mourn much less and generally provide no special rite, ceremony, or funeral for them, as we usually do for friends and families. ${ }^{i}$

Such miscarriages or aborted fetuses are normally dealt with as medical waste in the hospital, just like resected

\footnotetext{
i A very small number of religious groups do hold services for such events but mostly these are for the consolation and comforting of the bereaved parents.
}

tissues and organs. Rarely are they buried and remembered as "the deceased".

3. Intrauterine devices (IUDs) such as "copper T" are the most common form of reversible contraception, used by 85 million to 100 million women worldwide. ${ }^{8}$ Through inducing a mild inflammatory reaction inside the uterus, an IUD prevents the "fertilised egg" or "pre-embryo" implanting in the uterine endometrium. However, the use of an IUD is not perceived, by those who use it, as "killing an innocent human being".

4. The morning after pill, which women take within 72 hours of unprotected sex, causes a hormonal surge that stimulates the uterine lining to increase, leading to break through menstruation. It works to prevent the implantation of fertilised eggs or to induce a washout of the embryos.

5. In many countries, the law allows abortion to be performed before the end of the second trimester or up to 24 weeks (or 20 weeks), after which regulation becomes stricter. This suggests a general consensus that the fetus's moral status increases as it becomes more mature.

6. Creating embryos for in vitro fertilisation (IVF) treatment then discarding the surpluses afterwards, or after years of freezing them, is a quite common procedure of infertility therapy. This practice also does not treat human embryos as persons.

In these common social medical legal practices, human embryos are clearly not afforded equal moral status with adult humans. The protection required or due to them seems, however, to increase gradually or "by gradation" as they approach term. Such concepts can also be found in Aristotle's and Aquinas's thinking. Aristotle held that the male sperm conveys "pneuma" to the female menstrual blood and causes the developing embryo to have a soul or life. The rational soul begins in the male at about 40 days-and in the female about 90 days-from the entry of "pneuma" into the uterus. From then on the fetus has to be protected as potentially human. ${ }^{9}$ Aquinas adopted the entire doctrine 15 centuries later. Therefore they are both "gradualists" believing that the early embryo was less valuable than the later fetus."

\section{RELIGIOUS PERSPECTIVES AND BIOETHICS REPORTS}

Although the Vatican considers embryos to be inherently valuable from conception, ${ }^{10}$ many religions recognise embryos as having a moral status after a certain stage and as being a special entity between "all" or "none". Conservative and Orthodox Judaism-for example, assigns greater importance to embryos 40 days after conception. ${ }^{11}$ The Sunni and Shia branches of Islam believe that ensoulment, which takes place around the fourth month of gestation, is the process that endows embryos with moral value. ${ }^{11}$ Both faiths reject the "all" or "none" positions in favour of the view that the acquisition of moral value is a gradual process.

The gradualist position is also reflected in the bioethics reports or legal regulations of many countries-for example, the UK Department of Health report, Stem Cell Research: Medical Progress with Responsibility says: "The current restrictions and controls on embryo research reflect this...view, providing the human embryo with a degree of protection in law but allowing the benefits of the proposed research to be weighed against the respect due to the embryo". ${ }^{12}$ The Supreme Court of Canada held that fetuses are "unique" but not persons under the law. ${ }^{13}$ Health Canada's working group on embryo research also identifies a human embryo as having special status as a human entity but less than children or adults. ${ }^{14}$

Therefore, having examined the social, medical, religious, and legal practices, and their underlying common moral 
intuitions, the author proposes that if we are to establish a certain degree of consensus concerning human embryo research in a world awash with a conflict of moral opinions, this third position, which could be described as a "gradualist approach", is comparatively more plausible and acceptable than the other two extreme positions.

\section{THE MENCIUS IDEA OF PERSONHOOD}

There was no specific discussion of modern bioethical controversies such as the moral status of human embryo and research on them in the Confucian Classics, known simply as the Four Books. Nevertheless, Mencius, the greatest successor of Confucius, has described notions akin to personhood that are interesting and relevant.

Slight is the difference between men and the brutes. The common man loses this distinguishing feature, while the superior man (chun-tze) retains it. Shun understood the way of things and had a keen insight into human relationship. He followed the path of humanity (jen) and righteousness (yi). ${ }^{1 \text { ii }}$

\section{Then Mencius argued:}

\begin{abstract}
When I say all men have the mind which cannot bear to see the suffering of others, my meaning may be illustrated thus: Now, when men suddenly see a child about to fall into a well, they all have a feeling of alarm and distress, not to gain friendship with the child's parents, nor to seek the praise of their neighbours and friends, nor because they dislike to have the reputation of lack of humanity if they did not rescue the child. In such a case, we see that a man without the feeling of commiseration is not a man; a man without the feeling of shame and dislike is not a man; a man without the feeling of deference and compliance is not a man; and a man without the feeling of right and wrong is not a man. The feeling of commiseration is the beginning of humanity (jen); the feeling of shame and dislike is the beginning of righteousness (yi); the feeling of deference and compliance is the beginning of propriety (li), and the feeling of right and wrong is the beginning of wisdom (zhi). Men have these Four Beginnings just as they have their four limbs. Having these Four Beginnings, but saying that they cannot develop them is to destroy themselves... ${ }^{16}$
\end{abstract}

According to Mencius, then, what distinguishes men from animals are the inborn moral capacities of humanity (jen), righteousness (yi), propriety (li), and wisdom (zhi), which Mencius called the Four Beginnings. These moral potentialities bring one's life worth and dignity, and make persons worthy of respect, yet these Four Beginnings need to be realised. Obviously, the natural moral capacity of feeling right or wrong is a faculty of rationality, whereas the feelings of commiseration, shame, and dislike, and of deference and compliance require the agent to be self conscious. From this point of view, Mencius's definition of a person is compatible with the modern Western concepts of personhood. It is unclear, however, whether human beings who cannot develop (severely mental impaired infants) or who have lost (the advanced Alzheimer or patients in a permanent vegetative state) or who have not yet developed (embryos, fetuses, and small infants) such capacities-in Mencius's terms possessing in effect no moral faculties of humanity, righteousness, propriety, and wisdom-can still be counted as persons.

\section{CONFUCIUS'S THEORIES OF THE "LOVE OF GRADATION" AND "DUE TREATMENT"}

Based on the common social and medical practice described above, let us assume that the Confucian viewpoint on the moral status of human embryos is also a gradualist one, instead of "all" or "none". If one tries to extrapolate from Confucius's ethical theories, what position and conclusion might one have regarding stem cell research? How should we treat human embryos when research on them could create enormous human welfare?

The fundamental theories of Confucius's ethics can be summarised as: the merging of self cultivation and social political reform; the pursuit of dao; the ethical system of jen (humaneness), yi (righteousness), and li (rules of propriety); the moral ideal of chun-tze (the superior man or gentleman), and the wu-lun (five basic human relationships). ${ }^{17}$ Among these theories, the principle of humaneness (jen) and the principle of righteousness (yi) are prominent in Confucius's ethics and will be adopted in the ethical deliberation on human embryos research.

\section{The principles of jen and the "love of gradation"}

Jen has been translated into different words such as love, benevolence, humanity, human heartedness, perfect virtue, true manhood, and humaneness. In his reply to his disciples' queries concerning jen, Confucius gave different answers depending on the circumstances presented to him. Just to name the two central formulations. First, jen as the golden rule: Confucius defined jen both negatively: "Do not do to others what you do not want them to do to you", ${ }^{18}$ and positively: "A man of jen, wishing to establish his own character, also establishes the character of others, and wishing to be prominent himself, also helps others to be prominent" (Chan, ${ }^{16} \mathrm{p}$ 31). In combination, jen actually denotes avoiding harm (what they do not wish) to others, being concerned with their welfare, and helping them to attain what they wish. Second, jen as love: when Fan Chin asked about jen, Confucius gave him the most direct and essential answer: "It is to love men" (Chan, ${ }^{16}$ p 40). Love was the core of Confucius's concept of morality. This love in Confucius's ethics has a particular characteristic, which is called "the love of gradation".

\section{The love of gradation}

Confucius's ethics was grounded in the natural ties of affection and respect in the family, and took this biological bond as the fundamental unit upon which to construct the whole society: good breeding learned in and from the family constituted the moral framework of the society. Love and respect for fellow persons came originally as an extension of the affection learnt and shared in the family. When Yang Chu taught "self love" or egoism and Mo Ti taught "universal love", Mencius challenged them vehemently arguing:

Yang advocated egoism, which means a denial of the special relationship with the ruler. Mo advocated universal love, which means a denial of the special relationship with the father. To deny the special relationship with the father and the ruler is to become birds and beasts... If the principles of Yang and Mo are not stopped, and if the principles of Confucius are not brought to light, perverse doctrines will delude the people and obstruct the path of humanity (jen) and righteousness (yi) (Chan, ${ }^{16}$ p 72).

Confucius's ethics emphasise the natural gradational pattern of human love. ${ }^{19}$ That a mother loves and devotes herself to the care of her own child before looking after other people's children is an unexceptional characteristic of human 
nature; a "partiality" that is undeniably a "universal" truth. Suppose I am willing to donate a kidney for my daughter, who is now on renal dialysis, while at the same time a stranger also needs it badly. According to Mo Ti's selfless, universal love, both of them should be entitled to the equal opportunity to receive my organ because universal love allows no gradational treatment. However, to argue that this stranger has the same claim to my organ as my daughter seems inconceivable and counter to our basic common sense. Universal love, from the viewpoint of Mencius, is a moral ideal based on love and affection shared within families and applied to strangers. What worried Mencius was not the Moist universalism and ethical idealism but the impracticability of the whole process. Our good intention of caring for strangers as dearly as we care for our parents may lead some day to us treating our dearly beloved as apathetically as we treat passers by. ${ }^{20}$ The bond and affection originating from within family is the foundation of Confucius's moral theory, and its position is higher and takes precedence over the morality between strangers. The "attention to the scope" of altruism is hence clearly defined in Confucius's ethics, which gives the principle of beneficence a pragmatic formula. ${ }^{17}$

Mencius said:

In regard to inferior creatures, the superior man is kind to them, but not loving. In regard to people generally, he is loving to them, but not affectionate. He is affectionate to his parents, and lovingly disposed to people generally. He is lovingly disposed to people generally, and kind to creatures. ${ }^{21}$

The man of humanity (jen) loves all, but he considers the effort to cultivate an affection for the worthy to be the most urgent (Chan, ${ }^{16} \mathrm{p}$ 81).

The man of humanity (jen) begins with what he cares for and proceeds to what he does not care for" (Legge, ${ }^{21} \mathrm{p}$ 477). iii

His most cited maxim advocates:

Treat with respect the elders in my family, and then extend that respect to include the elders in other families. Treat with tenderness the young in my own family, and then extend that tenderness to include the young in other families (Chan, ${ }^{16} \mathrm{p}$ 61).

The gradation pattern in the principles of jen and $y i$ also gave form to the rules of propriety (li). Therefore, Confucius said:

Humanity (jen) is the distinguishing characteristic of man, and the greatest application of it is being affectionate toward relatives. Righteousness (yi) is the principle of setting things right and proper, and the greatest application of it is in honouring the worthy. The relative degree of affection we ought to feel for our relatives and the relative grades in the honouring of the worthy give rise to the rules of propriety (li)" (Chan, ${ }^{16} \mathrm{p} \mathrm{104)}$.

From these accounts, we can understand that Confucius's "love of gradation" is remarkably different from "self love" and "universal love". It is a product of the society of blood relationships, feudalism, and the patriarchal clan system, yet it described the role of natural human bonding in moral theory, which chimes with the "relationship awareness", "particularity", and "partiality" as advanced by certain feminist ethics and "ethics of care".

\section{The principle of yi and "due treatment"}

The second important Confucian moral principle to be considered is the principle of $y i$. The Chinese word $y i$ is composed of two characters, a "sheep" above an "I". It symbolises an exalted person holding a sacrificial animal on his head to dedicate it to god. Therefore, " $y i$ " signifies the state of a man carrying an appropriate sacrifice with a respectful mind toward heaven/god in a right time, place, and way. Confucius's principle of yi generally means righteousness, appropriateness, and justice. The first two meanings of $y i$ are more relevant to the author's argument regarding embryo research. Firstly, $y i$ as righteousness: $y i$ is the standard for moral judgment and the way to evaluate whether the application of moral rules is correct. Confucius said: "The superior man regards righteousness $(y i)$ as the substance of everything..." (Chan, ${ }^{16}$ p 43) and "...in dealing with the world...he follows righteousness (yi) as the standard" (Chan, ${ }^{16} \mathrm{p} \mathrm{26}$ ). Confucius stressed that things must be done in a righteous way (yi); even wealth and honour, no matter how desirable they are, cannot be obtained "unrighteously" (Chan, ${ }^{16}$ p 26). ${ }^{\text {iv }}$

Secondly, $y i$ as appropriateness: Confucius said: "Yi is the principle of setting things to be appropriate" (Chan, ${ }^{16} \mathrm{p}$ 104). Yi hence entails "doing the right thing in an appropriate manner with time, place and circumstances considered." How is this achieved? Confucius gives us two concepts that are useful: (1) Chuan (flexibility): remain resilient in applying moral rules so as to achieve what is most appropriate in every particular situation and to satisfy the standard of $y i$, (Legge, ${ }^{18}$ pp 217, 337) (Chan, ${ }^{16}$ p 76) and (2) Chung-yung (the doctrine of the Mean): balancing the complementary virtues and the competing moral principles in self moral cultivation and in actual ethical decision making (Chan, ${ }^{16}$ p 96) (Legge, ${ }^{18} \mathrm{p} 382$ ). Thirdly, $y i$ as "justice". This is generally concerned with regulating selfish desires and limiting the endless pursuit of self profit; a fair acquisition and distribution of resources, and the prioritisation of justice before profit, and public interest before self interest. ${ }^{17}$

The principle of $y i$ "as appropriateness" hence encompasses the conception of "due treatment". It was described in the Confucian Analects: "Some asked, "What do you think of repaying hatred with virtue?' Confucius said: 'In that case what are you going to repay virtue with? Rather, repay hatred with uprightness (chih, impartiality) and repay virtue with virtue" ${ }^{\prime \prime}$ (Chan, ${ }^{16}$ p 42). This clearly implies the importance of "the due treatment for one is deserved (desert)" and "the fair and appropriate entitlement for people".

Another two stories also show the Confucian way of combining "the love of gradation" and the "due treatment for persons and creatures". First: "A certain stable was burned down. On returning from court, Confucius asked, 'Was any man hurt?' Confucius did not ask about the horses" (Chan, ${ }^{16} \mathrm{p} \mathrm{36}$ ). This indicates that our moral obligations toward persons are much more important than those toward animals (in Confucius's time horses were probably more expensive than human slaves.)

Second, a fictitious ethical dilemma was created by Tao Ying to challenge Mencius and Mencius gave an intriguing answer.

Tao Ying asked, saying: "Shun being sovereign, and Kaoyao chief minister of justice, if Ku-sau (Shun's father) had murdered a man, what would have been done in the case $?^{\prime \prime}$

Mencius said: "Kao-yao would simply have apprehended him."

ii, iii, iv Translation modified by the author. 


\begin{abstract}
"But would not Shun have forbidden such a thing?"
"Indeed, how could Shun have forbidden it? Kao-yao had received the law from a proper source."

"In that case what would Shun have done?"

"Shun would have regarded abandoning the kingdom as throwing away a worn out sandal. He would privately have taken his father on his back, and retired into concealment, living somewhere along the sea coast. There he would have been all his life, cheerful and happy, forgetting the kingdom" (Legge, ${ }^{18}$ pp 469-70).
\end{abstract}

Mencius recognised the general validity of law but considered that Shun's love and filial piety for his father should take priority over his obligation to the state. Shun cannot sentence or send his father to death. Neither could he use sovereign authority to forbid the chief minister of justice from bringing his father to justice. However, Shun's love and filial piety for his father, despite the fact that his father was a murderer, would lead him to abandon the sovereignty and to flee, carrying his father to the distant sea coast where the law did not reach. Basically, Mencius was proposing that the moral values of parent/child love are more important than the glory of being and ruling as a sovereign. Shun would be "happy and cheerful" with his father in their concealment and would simply forget the kingdom that he had deserted as he would a worn out sandal.

In theory, Confucius regarded filial piety (shaw) and fraternal love (or brotherly respect) (ti) as the "root of humaneness (jen)", and advised that "a chun-tze (superior man) must devote himself to the fundamentals (the root) since when the root is firmly established, the moral law (dao) will grow" (Chan, $\left.{ }^{16} \mathrm{p} 20\right)$. All social goods are just extensions of good family ethics. Therefore, although Confucius advocated a persistent adherence to "righteousness", "appropriateness" and "justice", which were entailed in his principle of $y i$, he was reluctant to compromise what he considered to be fundamental-filial piety and fraternal love-in the face of moral conflicts. These are the roots of morality while other virtues are the branches. To sacrifice the roots in order to preserve the branches is simply illogical. Sometimes, it is plausible, even compulsory, for one to display unequal love and respect toward different subjects according to the psychological distance or blood ties. If the father (or son) committed a serious crime that caused tremendous damage to the public good, however, the principle of $y i$ as justice would certainly require one to put morality before profit and public interest before self interest. Flexibility in applying moral rules and balancing the conflicting moral values so as to achieve the due Mean and maintain righteousness (yi) are what Confucius's ethics has always advocated. It would be implausible to presume that filial piety and fraternal love, although holding a special position in Confucian ethics, should always have a priority over justice or law.

Consequently, the Confucian precepts of "the love of gradation" and the "due treatment for persons and creatures" will require one to show unequal love and treatment to the agents or objects involved according to one's relationship with them. The moral status of the agents or objects is certainly crucial, and this applies to human embryo research.

\section{CONCLUSION: THE LOVE OF GRADATION, DUE TREATMENT, AND HUMAN EMBRYO RESEARCH}

After reflecting on the two Confucian ethical concepts of "love of gradation" as derived from the principle of jen and "the due treatment to persons and creatures" as derived from the principle of $y i^{\prime}$, and the "gradualist moral status of the human embryo", the author has reached his conclusions:
1. Based on the common social/medical/legal, even religious, practices and their underlying moral intuitions, the most plausible position on the moral status of the human embryo is a gradualist one. The human embryo has less moral status and ethical significance than the later fetus, infant, child, and adult human. The moral obligation we have for (rational, conscious) persons is clearer and stronger than those we have for human embryos.

2. Human persons, who have throughout history suffered from all kind of diseases and disabilities, are now likely to have a better chance to be rescued, remedied, or relieved by human embryonic stem cell therapy, which requires conducting experiments on early human embryos. This needs to be done because we, either as bioscientists, doctors, and policy makers, or as a society, have a strong moral obligation toward our fellow persons and a duty to save vulnerable and valuable human lives. Therefore when the means of life saving and suffering relieving medical interventions seem feasible, we are driven by such moral duties to make the most of the opportunities that present themselves. Research on early human embryos is hence plausible and justifiable if it brings definite, enormous, and irreplaceable welfare to human persons that could not otherwise be achieved. The medical benefits and utility for human persons that can be created through human embryonic stem cell research are of such tremendous ethical significance, that they might even outweigh our moral obligation toward early human embryos and the duty not to harm.

3. The Confucian "love of gradation" is not, however, "selfish love" because it requires us to show and extend love and respect, by degree, toward entities other than persons according to the distance, difference, or moral status between us and them. This is very important, and is a distinctive contribution to bioethics from Confucius's ethics. Even if we accept that the moral status of the human embryo is a gradualist moral status, and that the early human embryo has less moral status and ethical significance than the later fetus and adult human, we can still recognise that human embryos are a special entity with a certain moral status and importance that deserves our ethical consideration. We should, therefore, be very cautious in using human embryos for research so as to acknowledge the gradualist nature of their moral status. The use of the human embryo for research-for example, should be allowed only under very limited conditions, when it is absolutely necessary. Strict regulation and supervision should be established. Embryo research projects must receive careful scientific and ethical review before being approved and performed. Due processes of informed consent from the embryo donors, etc, should be carried out rigorously.

4. The human embryonic stem cell is more pluripotent and useful than the adult stem cell, and through therapeutic cloning researchers are more likely to produce tailor made, rejection free tissues and cells for regenerative medicine: the medical utility of such cells will be ground breaking. Nevertheless, if, some day, scientists discover that using adult stem cells can achieve the same therapeutic effects as that which can be accomplished by embryonic stem cell therapy, then the use of human embryos for research would no longer be justified and should therefore be prohibited. At such a time we should adopt the Confucian theories of love of gradation, and extend our love and respect for fellow persons toward human embryos as using them is no longer absolutely necessary.

\section{ACKNOWLEDGEMENTS}

The author would like to thank Professor John Harris for his comments on the earlier draft of this paper, and the National Science Council, Taiwan and National Taiwan University Hospital for the sponsorship of the research necessary for this paper. 


\section{REFERENCES}

1 Warren MA. Moral status. Oxford: Oxford University Press, 1997:3

2 Devine PE. The species principle and the potential principle. In: Brody B, Engelhardt HT, eds. Bioethics: readings and cases. New Jersey, Englewood Cliffs: Prentice-Hall Inc, 1987:136-41.

3 Engelhardt HT. The foundation of bioethics. New York: Oxford University Press, 1986:104.

4 Fletcher J. Indicators of humanhood: a tentative profile of man. Hastings Cent Rep 1972;2:1-4.

5 Singer P. Practical ethics. Cambridge: Cambridge University Press, 1979:86.

6 Tooley M. The criterion of awareness of self as a continuing entity. In: Brody B Engelhardt HT, eds. Bioethics: readings and cases. New Jersey, Englewood Cliffs: Prentice-Hall Inc, 1987:146-52

7 Harris J. The value of life. London: Routledge, 1985:18.

8 Canavan TP. Appropriate use of the intrauterine device. Am Fam Physician, 1998;58, 2077-84

9 Warren $M$. Experimentation on human embryos and fetuses. In: Kush $\mathrm{H}$, Singer P, eds. A companion to bioethics. Oxford: Blackwell, 1998.

10 Congregation for the Doctrine of the Faith. Instruction on respect for human life in its origin and on the dignity of procreation. Vatican City: Congregation for the Doctrine of the Faith, 1987.

11 National Bioethics Advisory Commission. Ethical issues in human stem cell research, vol 3: religious perspectives. Rockville, MD. http://www.georgetown.edu/research/nrcbl/nbac/stemcell3.pdf laccessed 2 Feb 2005)

12 Department of Health. Stem cell research: medical progress with responsibility. http://www.dh.gov.uk/assetRoot/04/06/50/85/ 04065085.pdf (accessed 20 Feb 2005).

13 Shanner L, Nisker J. Bioethics for clinicians: 26 Assisted reproductive technologies. CMAJ 2001;164:1589-94.

14 Discussion Group on Embryo Research. Research on human embryos in Canada: final report. Ottawa: Health Policy Division, Health Canada, 1995.

15 Mencius [trans Lau DC]. Hong Kong: The Chinese University Press, 1984:165.

16 Chan WT. A source book in Chinese philosophy. New Jersey: Princeton University Press, 1969:65-6.

17 Tsai DFC. The bioethical principles and Confucius's moral philosophy. J Med Ethics 2005;31:159-63.

18 Confucian analects, The Chinese classics vol I [trans Legge J]. Hong Kong Hong Kong University Press, 1960:39.

19 Lin YT. From Pagan to Christian. New York: The World Publishing Company, 1959:86.

20 Tu WM. Confucian thought: selfhood as creative transformation. New York: State University of New York Press, 1985:123-4.

21 The work of Mencius, The Chinese classics vol II [trans Legge J]. Hong Kong: Hong Kong University Press, 1960:476.

\section{Notice}

\section{EACME Annual Meeting - Call for abstracts}

The 2006 EACME Annual meeting will be taking place on 28-30 September 2006 at the Catholic University of Leuven, Belgium. The focus of the conference is on four new developments in European bioethics: social sciences and bioethics; care ethics; bioethics, law, and politics; and new technologies and bioethics. Persons wishing to present papers at the conference are invited to submit an abstract addressing the ethical dimensions of the conference topics (500 words maximum) before 1 March 2006. For further information please contact Chris Gastmans, Centre for Biomedical Ethics and Law, Faculty of Medicine, K.U.Leuven, Kapucijnenvoer 35, 3000 Leuven, Belgium; tel: 0032163369 51; fax: 0032 163369 52; email: Chris.Gastmans@med.kuleuven.be. 